\title{
Peningkatan Kreativitas dan Hasil Belajar Sejarah Indonesia Kuno Melalui Optimalisasi Model Pemecahan Masalah Kreatif Dalam Proses Belajar Mengajar (PBM) di Prodik Sejarah FKIP - UNS
}

\author{
Akhmad Arif Musadad \\ FKIP - UNS, e-mail: arif mussadad fkip@yahoo.co.id
}

\begin{abstract}
Abstrak: Penelitian ini bertujuan untuk meningkatkan kreativitas dan hasil belajar mahasiswa tentang sejarah Indonesia kuno melalui optimalisasi model pemecahan masalah kreatif dalam pembelajaran di Program Studi Pendidikan Sejarah FKIP UNS. Metode penelitian menggunakan penelitian tindakan kelas. Subyek penelitian meliputi mahasiswa Program Studi Pendidikan Sejarah yang menempuh mata kuliah sejarah Indonesia kuno, dengan obyek: aktivitas mengajar dosen, kreativitas dan hasil belajar mahasiswa. Pendekatan penelitian ini dilaksanakan melalui partisipatif kolaboratif antara dosen pengampu, dosen pendamping (peneliti), dan mahasiswa. Penelitian dilakukan dengan proses pengkajian berdaur yang meliputi tahap perencanaan tindakan, pelaksanaan, pengamatan, dan refleksi. Penelitian ini dilaksanakan dalam dua siklus, yaitu siklus I sebagai implementasi tindakan dan siklus II sebagai perbaikan. Hasil penelitian menujukkan bahwa dari satu siklus ke siklus berikutnya kreativitas dan hasil belajar mahasiswa semakin meningkat. Hal itu tercermin dari peningkatan kedisiplinan mahasiswa dalam memanfaatkan waktu belajar, kemampuan mencari dan mengumpulkan sumber, kemampuan mengidentifikasi, merumuskan dan memecahkan masalah, dan tumbuhnya ide, gagasan dari mahasiswa.
\end{abstract}

Kata kunci: kreativitas belajar, hasil belajar, sejarah indonesia kuno, dan model pemecahan masalah kreatif.

\begin{abstract}
The objective of research is to improve the creativity and classic Indonesian history learning achievement through optimizing the creative problem solving model in teaching-learning process in History Study Program of FKIP UNS. This study was carried out using classroom action research. The subject of research was the students of History Study Program attending classing Indonesian history course. Meanwhile the object was the teaching-learning process activity, including: lecturer's teaching activity, students' creativity and learning achievement. This research was carried out using collaborative participative approach between the in-charge-of lecturer, assisting lecturer (researcher), and the student so that sharing occurs in each stage of activity. This research was done using cyclical analysis process encompassing four stages of activity: planning, acting, observing, and reflection. This research was implemented in two cycles: cycle I as the implementation of action, and cycle II as improvement. The result of this research shows that from one cycle to another the student's creativity and learning achievement improves. It is reflected from: the improvement of students discipline in utilizing learning time, capability of looking for and collecting the source, capability of identifying, formulating, and solving the problem, idea generation, students' idea.
\end{abstract}

Key words: learning creativity, learning achievement, Indonesian classic history, and creative problem solving model.

\section{Pendahuluan}

Pembelajaran sejarah berarti pembelajaran tentang peristiwa-peristiwa penting yang telah dialami manusia pada masa lampau yang berdampak besar terhadap kehidupan manusia. Mempelajari sejarah dapat menuntun siswa mengambil hikmah dari peristiwa sejarah tersebut untuk memahami masa kini dan merencanakan masa depan.

Widya (1989) mengemukakan tujuan pembelajaran sejarah mencakup tiga aspek, yaitu: a) aspek pengetahuan, b) aspek pengembangan 
sikap, dan c) aspek keterampilan. Aspek keterampilan telah sesuai dengan pembaharuan dalam pembelajaran sejarah yaitu pembelajaran dengan prinsip CBSA. Sehubungan dengan hal itu, maka dalam pembelajaran sejarah diharapkan dapat mengembangkan ketrampilan mengumpul-kan jejak-jejak sejarah, mengajukan argumentasi dan mendiskusikan masalah kesejarahan, menelaah buku-buku sejarah, mengajukan pertanyaan, dan bercerita tentang peristiwa sejarah secara hidup.

Meskipun para ahli telah menyampaikan pendapatnya mengenai bagaimana cara mengajarkan sejarah yang baik, namun di lapangan berkata lain. Para guru dan dosen pada umumnya mengajarkan sejarah hanya sekedar untuk memenuhi ingatan para peserta didik dengan berbagai fakta dan materi yang harus dihafalnya. Pembelajaran semacam ini kurang tepat, karena tidak menyentuh aspek keterampilan dan sikap peserta didik. Akibatnya peserta didik kurang termotivasi untuk belajar secara aktif dan mandiri. Peserta didik tidak terbiasa membaca buku-buku referensi, kurang berani mengemukakan pendapat, dan pada umumnya mengalami kesulitan untuk memecahkan suatu masalah.

Sebagai kasus, dalam kesempatan ini dapat dikemukakan pembelajaran Sejarah Indonesia Kuno di Program Studi Pendidikan Sejarah FKIP UNS. Selama ini pembelajaran Sejarah Indonesia Kuno terasa kering, karena dosen hanya menggunakan metode ceramah, sedangkan materi yang diajarkan hanya sebatas buku pegangan kuliah (BPK) yang sebenarnya sekarang tidak diberlakukan di UNS. Hal ini akan menimbulkan permasalahan, antara lain dosen kurang kreatif dan inovatif sehingga terjadi kejenuhan dalam pembelajaran Sejarah Indonesia Kuno.

Berdasarkan pengamatan yang diadakan peneliti terhadap pembelajaran Sejarah Indonesia Kuno di semester dua yang diampu oleh Drs. Herimanto, M.Pd., M.Si. dapat dikemukakan di sini: 1) Pada saat pembukaan, dosen tanpa berupaya untuk menumbuhkan motivasi mahasiswa, tidak menyampaikan tujuan, dan tidak mengadakan pree test. Jadi pada saat pembukaan yang dilaksanakan hanya mengabsen mahasiswa, dan langsung menyampaikan materi; 2) Pada saat penyajian materi dosen hanya menggunakan metode ceramah tanpa dikombinasikan dengan metode lain (misalnya diskusi dan penugasan), sehingga pembelajaran terkesan monoton dan membosankan. Hal ini berdampak pada rendahnya kreativitas mahasiswa, misalnya: mahasiswa pasif dalam mengikuti pelajaran, tidak ada upaya untuk mencari dan menganalisis sumber, dan tidak mencoba mencari akar suatu permasalahan dan upaya pemecahannya; 3) Dosen kurang menguasai materi, hal ini tampak dari: dosen mengajar hanya sekedar membaca slide dari power point tanpa improvisasi sebagai penjelasan materi; dan 4) Pada saat penutupan dosen pun hanya cukup mengucapkan salam, tanpa disertai usaha membuka kesempatan untuk bertanya jawab dengan mahasiswa, bahkan tidak ada rangkuman dari materi yang telah disampaikan.

Masalah pembelajaran yang terungkap dari pengamatan tim peneliti terhadap PBM tersebut kemudian digali lebih jauh melalui wawancara dan diskusi dengan: dosen, dan mahasiswa Prodik Sejarah.

Selanjutnya peneliti mengidentifikasi alternatif tindakan pemecahan, akhirnya disepakati bahwa masalah rendahnya kemampuan mengajar dosen yang berakibat pada rendahnya kreativitas dan hasil belajar mahasiswa, sangat mungkin berdampak juga pada faktor kejenuhan mahasiswa terhadap cara mengajar yang monoton, dan kurang menantang mahasiswa yaitu dengan metode ceramah.

Selanjutnya, peneliti mengadakan diskusi tentang beberapa model pembelajaran inovatif, di dalamnya juga dibahas tentang (sintaks, sistem sosial, prinsip reaksi, sistem pendukung, dan dampak instruksional serta pengiring) masingmasing model tersebut. Setelah mencermati karakteristik mahasiswa, dosen, dan mata kuliah yang bersangkutan, akhirnya peneliti berkesimpulan bahwa rendahnya kreativitas dan hasil belajar Sejarah Indonesia Kuno dapat diatasi dengan optimalisasi penerapan model pemecahan masalah kreatif (PMK).

Sebab pembelajaran sejarah tidak sekedar berisi cerita hafalan. Sejarah merupakan produk inquiry yang hanya dapat dimengerti dengan menganalisis data/fakta yang ada, ditinjau secara multi dimensional, kemudian dirangkai dalam hubungan sebab akibat. Mahasiswa tidak hanya diberi tahu tentang "apa", tetapi lebih mengacu 
pada "mengapa" dan "bagaimana" suatu peristiwa terjadi. Peristiwa sejarah kiranya akan lebih dapat dimengerti secara mendalam kalau dikaji lewat proses bertanya, dan kemudian mencoba untuk mencari jawabnya dengan pemecahan dari perbagai aspek kehidupan.

Berpijak dari uraian di atas, maka untuk meningkatkan kreativitas dan hasil belajar Sejarah Indonesia Kuno dalam PBM di Prodik Sejarah tim peneliti sepakat melakukan tindakan pemecahan berupa optimalisasi penerapan model pemecahan masalah kreatif, dengan langkahlangkah tindakan yang ditawarkan untuk mengatasi masalah tersebut adalah sebagai berikut: 1) Pendahuluan/ Orientasi; 2) Kegiatan inti, meliputi langkah-langkah: (a) Identifikasi masalah, (b) Perumusan masalah, (c) Pembagian kelompok dan sub kelompok, (d) Kajian di sub kelompok dan dilanjutkan diskusi kelompok, dan (e) Diskusi kelas; 3) Penutup, yaitu tahap pemantapan materi oleh dosen dan mahasiswa.

Permasalahan dalam penelitian ini dapat dirumuskan sebagai berikut: "Bagaimanakah upaya meningkatkan kreativitas dan hasil belajar Sejarah Indonesia Kuno melalui optimalisasi model pemecahan masalah kratif dalam PBM di Prodik Sejarah FKIP - UNS?". Penelitian ini bertujuan untuk meningkatkan kreativitas dan hasil belajar sejarah Indonesia kuno melalui optimalisasi model pemecahan masalah kreatif di Program Studi Pendidikan Sejarah FKIP- UNS.

\section{Kajian Literatur}

Tugas dan tanggung jawab yang utama bagi seorang guru adalah mengajar Mengajar berarti juga membantu siswa dalam pertumbuhannya, kegiatan ini mengarah pada suatu tujuan (B. Simanjuntak dan LL. Pasaribu, 1986). Menurut Nasution (1995) mengajar adalah suatu usaha dari pihak guru untuk mengatur lingkungan, sehingga tercipta suasana kondusif yang memungkinkan siswa untuk belajar. Hal ini Senada dengan pendapat Brown (1975) bahwa "good teaching is in the eyes of the beholders, successful teaching is in the performance of the pupils".

Terlepas dari uraian yang sifatnya teoretis di atas, dalam praktiknya pembelajaran sejarah masih banyak ditemukan kendala. Sejarah dianggap sebagai mata pelajaran yang mem- bosankan dan tidak menarik, karena harus menghafalkan peristiwa yang pernah terjadi di masa lampau yang tidak ada gunanyanya. Meskipun demikian para ahli telah menyatakan bahwa sejarah itu memiliki kegunaan, yaitu: guna edukatif, guna inspiratif, dan guna rekreatif dan instruktif.

Sejarah memiliki guna edukatif karena sejarah dapat memberikan kearifan bagi yang mempelajarinya, yang secara singkat dirumuskan oleh Bacon: "histories make man wise". Sejarah yang memberikan perhatian pada masa lampau tidak dapat dipisahkan dari kemasakinian, karena semangat dan tujuan untuk mempelajari sejarah ialah nilai kemasakiniannya. Hal ini tersirat dari kata-kata Croce bahwa "all history is contemporary history", yang kemudian dikembangkan oleh Carr bahwa sejarah adalah "unending dialogue between the present and the past" (Widja, 1988). Dari pernyataan-pernyataan di atas, dapat disimpulkan bahwa apabila kita dapat memproyeksikan masa lampau ke masa kini, maka kita dapat menemukan makna edukattif dalam sejarah.

Sejarah memiliki guna inspiratif karena sejarah dapat memberikan inspirasi kepada kita tentang gagasan-gagasan dan konsep-konsep yang dapat digunakan untuk memecahkan persoalan-persoalan masa kini, khususnya yang berkaitan dengan semangat untuk mewujudkan identitas sebagai suatu bangsa dan pembangunan bangsa.

Sejarah memiliki guna rekreatif karena dengan membaca tulisan sejarah kita seakanakan melakukan "perlawatan sejarah" karena menerobos batas waktu dan tempat menuju zaman masa lampau untuk "mengikuti" peristiwa yang terjadi. Sementara itu guna instruktif merupakan kegunaan sejarah untuk menunjang bidang-bidang ketrampilan tertentu (Nugroho Notosusanto, 1979).

Sementara itu banyak ahli yang teorinya berpengaruh dalam pembelajaran sejarah, diantaranya Piaget, Bruner, dan Blomm (Gunning, 1978). Pengaruh utama dari ketiga pemikir tersebut adalah pengembangan berpikir kreatif dalam pembelajaran sejarah. Pembelajaran sejarah tidak dapat disamakan dengan cerita hafalan. Ilmu sejarah memerlukan cara khusus untuk menyampaikannya. Sejarah merupakan 
produk inquiry yang hanya dapat dimengerti dengan menganalisis data/ fakta yang ada ditinjau dari berbagai sudut pandang (multi dimensional), kemudian dirangkai dalam hubungan sebab akibat. Siswa tidak cukup diberi tahu tentang: apa, kapan, siapa, dan di mana; tetapi yang lebih penting adalah: mengapa, dan bagaimana suatu peristiwa sejarah terjadi. Peristiwa sejarah kiranya akan lebih dapat dimengerti secara lebih mendalam jika dikaji lewat proses bertanya dan kemudian mencoba untuk mencari jawabnya dengan pemecahan berbagai masalah. Oleh karena itu, Pemecahan Masalah Kreatif yang dikembangkan oleh Treffinger (1980) dan Parnes (1981) perlu dicobakan dalam pembelajaran sejarah.

Menurut Treffinger (1980), pemecahan masalah kreatif terdiri dari tiga tingkatan. Tingkat pertama mendukung tingkat kedua, untuk selanjutnya bersama-sama mendukung tingkat ketiga. Teknik kreatif tingkat pertama bertujuan membantu siswa agar bersifat terbuka untuk menerima gagasan baru, sehingga dalam diri mereka terdapat usaha untuk mencari alternatif penyelesaian masalah. Pada tingkatan kedua, siswa diajak untuk memperluas pikiran dan berperan dalam kegiatan yang lebih majemuk dan menantang. Pada tingkat ketiga adalah pemecahan masalah kreatif (PMK), yaitu cara sistematis dalam mengorganisasi dan mengolah keterangan atau gagasan sehingga persoalan dapat dipecahkan secara imaginatif.

Pemecahan masalah kreatif adalah model pembelajaran yang mengembangkan pemikiran divergen, dan berusaha mencari berbagai alternatif dalam memecahkan suatu masalah. Model pemecahan masalah kreatif ini sangat berpotensi untuk melatih siswa dalam menyelesaikan persoalan yang berkaitan dengan pengembangan berpikir divergen. Ini mengandung implikasi bahwa pengembangan potensi siswa akan menghasilkan kemampuan berpikir yang memuaskan. Dalam pemecahan suatu masalah, pengerahan potensi yang telah dimiliki siswa akan lebih berdaya guna dari pada sekedar mengandalkan penjelasan sepihak dari guru.

Dengan demikian, dapat diasumsikan bahwa: optimalisasi penerapan model pemecahan masalah kreatif dapat meningkatkan kreativitas mahasiswa, dan pada gilirannya dapat meningkatkan hasil belajar sejarah Indonesia kuno.

\section{Metode Penelitian}

Penelitian ini dilaksanakan di Prodi Sejarah Jurusan PIPS FKIP - UNS, yang terletak di Kampus Kentingan, Jalan Ir. Sutami No. 36 A Surakarta. Penelitian ini dilaksanakan selama delapan bulan, yaitu mulai Maret hingga Oktober 2010. Subjek dalam penelitian ini adalah mahasiswa yang mengambil Mata Kuliah Sejarah Indonesia Kuno, yang berjumlah 90 mahasiswa. Sedangkan objeknya adalah kegiatan belajar mengajar.

Data yang diperlukan dalam penelitian ini berupa informasi tentang: aktivitas mengajar dosen, aktivitas belajar mahasiswa, suasana pembelajaran, dan prestasi belajar mahasiswa. Teknik yang digunakan dalam pengumpulan data adalah: wawancara, observasi, dan kajian dokumen. Pemeriksaan atau validitas data yang dilakukan dalam penelitian ini adalah trianggulasi sumber, yaitu dengan cara mengecek, membandingkan data dari satu sumber dengan data dari sumber yang lain.

Teknik yang digunakan untuk menganalisis data-data yang telah terkumpul dalam penelitian ini adalah teknik analisis kritis. Teknik ini digunakan untuk mengungkapkan segala kelebihan dan kekurangan aktivitas dosen dan mahasiswa selama proses belajar mengajar berlangsung. Hasil analisis tersebut dijadikan sebagai dasar untuk merencanakan tindakan berikutnya. Di samping itu, dalam penelitian ini juga menggunakan teknik analisis komparatif, artinya data-data yang tampak dari proses belajar mengajar dalam satu tahap dan satu siklus dibandingkan dengan data-data PBM pada tahap dan siklus berikutnya. Dengan teknik ini dapat diketahui kemajuan kinerja dosen dan mahasiswa dalam PBM dari setiap siklusnya.

Penelitian ini dilaksanakan dengan metode classroom action research atau yang sering dinamakan penelitian tindakan kelas (PTK). Melalui PTK para guru dan dosen LPTK langsung memperoleh teori yang dibangunnya sendiri bukan yang diberikan oleh pihak lain, maka guru menjadi the theorizing practitioner (Tim Pelatih Proyek PGSM, 1999).

Jenis penelitian ini sangat praktis, untuk 
memperbaiki atau meningkatkan mutu pembelajaran di kelas, dan upaya perbaikannya dilakukan dengan melaksanakan tindakan untuk mencari jawaban atas permasalahan yang diangkat dari tugas sehari-hari di kelas (Kasihani Kasbolah, 2001). Penggunaan metode ini didasarkan pada asumsi bahwa kualitas pembelajaran dapat diatasi guru sebagai langkah perbaikan profesionalisme dengan memberi kebebasan pengembangan kurikulum, materi, dan strategi pembelajaran. Masalah teridentifikasi, dipahami, dan dipecahkan secara kolaboratif (Hopkins, 1993), sehingga ditemukan alternatif terbaik.

Penelitian ini bersifat situasional, artinya tindakan perbaikan yang dilakukan, dirancang khusus dalam Pembelajaran sejarah Indonesia Kuno di Prodik Sejarah FKIP - UNS, sehingga belum tentu tepat jika diterapkan pada mata kuliah maupun program studi dan jurusan yang lain.

Penelitian ini dilakukan dengan pendekatan Partisipatif Kolaboratif antara peneliti, pimpinan prodik, dan mahasiswa, sehingga terjadi sharing dalam setiap tahap kegiatan. PTK dapat didefinisikan sebagai penelitian yang bersifat reflektif, yang dilakukan untuk meningkatkan kemantapan rasional dari tindakan-tindakan nyata dalam melaksanakan tugas, memperdalam pemahaman terhadap tindakan yang dilakukannya, serta memperbaiki kondisi di mana praktikpraktik pembelajaran tersebut dilakukan. Untuk mewujudkan tujuan tersebut, PTK dilaksanakan dengan "proses pengkajian berdaur" (cyclical), yang meliputi empat tahap kegiatan, yaitu: perencanaan (planning), tindakan (action), pengamatan (observation), dan refleksi (reflection). Pelaksanaan penelitian ini dilakukan dalam dua siklus, yaitu siklus I sebagai implementasi tindakan, sedangkan siklus II sebagai perbaikan.

Sebelum menyusun rencana tindakan, pada awal penelitian ini dilakukan pengidentifikasian dan penetapan masalah penelitian. Secara keseluruhan penelitian ini dilakukan sebagai berikut:

\section{Siklus Pertama Persiapan Tindakan}

Beberapa kegiatan yang dilakukan pada tahap ini adalah: diskusi tentang pembelajaran sejarah
Indonesia kuno, diskusi tentang metode dan strategi pembelajaran, latihan penyusunan rencana pelaksanaan pembelajaran, dan mengadakan les model pembelajaran untuk meningkatkan keterampilan dosen dalam menerapkan model pemecahan masalah kreatif dan meningkatkan kemampuannya dalam melaksanakan prosedur pembelajaran.

\section{Pelaksanaan Tindakan}

Berdasar persiapan dan rencana yang telah dimatangkan, maka dosen peneliti melaksanakan tindakan dalam proses belajar mengajar di kelas. Adapun pelaksanaan pembelajaran pada siklus pertama ini jatuh pada hari Senin tanggal $24 \mathrm{Mei}$ 2010. Dalam kesempatan tersebut, jika dosen peneliti mengajar, maka anggota tim peneliti yang lain bertugas sebagai observer. Pembelajaran ini dimaksudkan untuk mengkondisikan mahasiswa. Karena jumlah mahasiswa yang sangat besar yaitu 90 mahasiswa, maka dalam pelaksanaan model pemecahan masalah kreatif ini pembagian kelompok dilakukan untuk dua kali pertemuan, yaitu pertemuan tanggal 24 dan 31 Mei 2010. Ini dimaksudkan agar pembagian kelompok bisa merata, dan perkelompoknya tidak terlalu banyak mahasiswanya.

\section{Observasi}

Secara garis besar hasil observasi terhadap proses belajar mengajar yang diselenggarakan pada siklus pertama adalah sebagai berikut: 1). Dari segi penyusunan rencana pelaksanaan pembelajaran dapat dikemukakan hal-hal sebagai berikut: (a) perumusan kompetensi dasar telah relevan dengan standar kompetensi, namun masih terdapat kata kerja yang kurang operasional misalnya kata-kata: mengetahui, dan memahami, (b) tujuan pembelajaran sudah mengacu pada kompetensi dasar, namun lagi-lagi masih menggunakan kata kerja yang tidak operasional seperti contoh di atas, (c) pengembangan materi pembelajaran sesuai dengan rumusan kompetensi dasar, (d) penyusunan langkah-langkah/strategi pembelajaran sesuai dengan alur kegiatan yang dilaksanakan di dalam kelas, (d) pencantuman sumber dan media pembelajaran jelas, dan (e) perencanaan alat dan prosedur penilaian yang kurang jelas, sudah ada 
soal dan kunci jawaban, namun belum ada kunci skoringnya; 2) Dosen telah melak-sanakan prosedur pembelajaran dengan baik, hal ini terrefleksi dari: (a) Pada saat pendahuluan, dosen telah mengkondisikan suasana pembelajaran, dan memberiikan pengantar ke arah topik pembahasan (b) Pada saat kegiatan inti dosen mampu memimpin mahasiswa dalam: mengidentifikasi dan merumuskan masalah, membagi kelompok dan sub kelompok, Dan memimpin diskusi kelas (c) Pada saat penutupan dosen berusaha membuat kesimpulan, dan melontarkan beberapa pertanyaan kepada beberapa mahasiswa secara acak (d) Di samping hal-hal di atas, dosen juga: (1) menguasai materi yang disampaikan, dan (2) perhatiannya merata ke seluruh mahasiswa. Meskipun sudah terjadi banyak peningkatan dalam pelaksanaan PBM, namun kekurangannya juga masih ada, yaitu: (a) suaranya kurang jelas, (b) dosen terlalu sering melucu, dan (c) dosen tidak bersikap tegas dalam menghadapi mahasiswa yang mengganggu ketertiban kelas. Beberapa kelemahan lain pada saat pelaksanaan pembelajaran, kaitannya dengan penerapan model pemecahan masalah kreatif, adalah: (a) pembentukan kelompok hanya dilakukan berdasar tempat duduk, sehingga pembagian kelompok tidak merata baik dari jenis kelamin maupun tingkat kemampuannya, dan (b) dosen tidak mentaati alokasi waktu yang telah direncanaka, sehingga waktunya molor; 3) Kreativitas dan hasil belajar mahasiswa belum menunjukkan peningkatan secara signifikan. Hal itu dapat dikemukakan sebagai berikut: (a) mahasiswa kurang kreatif dalam memanfaatkan sumber, (b) mahasiswa kurang mampu mengeksplorasi masalah, (c) mahasiswa kurang disiplin dalam memanfaatkan waktu belajarnya, (d) selama diskusi berlangsung, hanya beberapa mahasiswa yang aktif, (d) suasana kelas waktu diskusi berlangsung tampak kaku, dan diskusi masih sering macet.

\section{Analisis dan Refleksi}

Dari hasil analisis dan refleksi atas tindakan yang dilakukan dalam PBM pada siklus pertama dapat dikatakan bahwa dosen telah mengajar lebih baik dibandingkan sebelumnya. Meskipun demikian kemampuan tersebut masih perlu ditingkatkan lagi, sebab masih tampak adanya beberapa kelemahan dalam pembelajaran tersebut. Karena masih ada kelemahan-kelemahan itu lah sehingga kreativitas dan hasil belajar mahasiswa belum meningkat secara berarti.

\section{Siklus Kedua \\ Rencana Perbaikan dan Tindakan}

Berpijak dari hasil Analisis dan refleksi dan hasil observasi pada siklus pertama, maka dalam siklus kedua ini diadakan perbaikan rencana untuk meningkatkan kemampuan dosen dalam pembelajaran. Adapun perbaikan yang dimaksud adalah sebagai berikut: 1) Kelemahan dalam penyusunan RPP dinilai tidak terlalu prinsip, sehingga dosen disarankan menyusun RPP secara mandiri dengan catatan memperhatikan beberapa kelemahan sebelumnya. Selanjutnya RPP dikonsultasikan dengan tim peneliti sebelum diimplementasikan dalam pembelajaran; 2). Untuk mening-katkan kreativitas dan hasil belajar mahasiswa, maka dosen harus lebih mengoptimalkan kemampuannya dalam menerapkan model pemecahan masalah kreatif. Karena itu tim peneliti merasa perlu mengadakan les model pembelajaran lagi.

\section{Pelaksanaan Tindakan}

Setelah rencana perbaikan ditetapkan dan persiapan dilaksanakan sebagaimana diuraikan pada bagian sebelumnya, dosen peneliti kemudian mengimplementasikannya dalam proses belajar mengajar di kelas. Kegiatan belajar mengajar dilaksanakan pada hari Senin tanggal 14 Juni dan Jumat 18 Juni 2010.

\section{Observasi}

Secara garis besar hasil observasi terhadap proses belajar mengajar yang diselenggarakan pada siklus kedua adalah sebagai berikut: 1 ) Penyusunan Rencana Pelaksanaan Pembelajaran RPP yang disusun pada siklus kedua ini sudah cukup baik. Meskipun pada siklus pertama masih ada kekurangan sebagaimana yang telah diuraikan sebelumnya, tetapi pada siklus kedua ini dari satu pertemuan ke pertemuan berikutnya terus mengalami perbaikan; 2) Dosen telah melaksanakan prosedur pembelajaran yang lebih baik dari siklus I, hal ini terrefleksi dari: (a) Pada 
saat pendahuluan, dosen telah mengkondisikan suasana pembelajaran, mengadakan appersepsi, dan menjelaskan konpetensi serta garis besar materi yang akan disampaikan (b) Pada saat kegiatan inti dosen lebih trampil memimpin mahasiswa: mengidentifikasi dan merumuskan masalah, dosen juga telah membagi kelompok dan sub kelompok, dan akhirnya dosen juga mampu memimpin diskusi kelas. Bahkan kekurangan yang terjadi pada siklus I yaitu pembagian kelompok yang hanya didasarkan pada tempat duduk, pada siklus II telah diperbaiki. (c) Pada saat penutupan dosen berusaha membuat kesimpulan dari apa yang telah disampaikan/ didiskusikan, dosen juga melontarkan beberapa pertanyaan kepada beberapa mahasiswa secara acak. (d) Beberapa kelebihan yang sudah terlihat pada siklus I juga tetap dipertahankan pada siklus II; 3). Kreativitas dan hasil belajar mahasiswa telah menunjukkan peningkatannya secara signifikan. Hal itu diantaranya terlihat dari: (a) mahasiswa kreatif dalam menggunakan sumber; (b) mahasiswa kreatif dalam mengidentifikasi dan merumuskan masalah; (c) mahasiswa kreatif dalam mengeksplorasi dan membahas masalah; (d) bahkan dalam diskusi pun kreativitas mahasiswa sangat tampak, misalnya dalam mengeluarkan ide, gagasan, maupun pendapat. Di samping itu mahasiswa mulai terlihat disiplin dalam memanfaatkan waktu belajarnya, misalnya: sudah tidak ada yang terlambat masuk kelas, dan selama pelajaran berlangsung pun sudah tidak ada yang berbisikbisik dan ramai sendiri. Suasana kelas selama pembelajaran berlangsung juga kelihatan kondusif, sehingga mahasiswa dapat belajar dengan baik.

\section{Analisis dan Refleksi}

Hasil observasi terhadap KBM sejarah Indonesia kuno yang dilaksanakan oleh peneliti pada siklus kedua ini telah berjalan dengan baik. Pembelajaran yang telah diobservasi dalam dua kali pertemuan pada siklus kedua ini, yaitu tanggal 14 dan 18 Juni 2010 pada umumnya mengalami kemajuan dari satu pertemuan ke pertemuan berikutnya. Pada pertemuan kedua dari siklus kedua ini dosen peneliti telah mampu mengadopsi dan mengaplikasikan semua tidakan yang telah dirancang bersama tim peneliti yang lain dalam PBM sehingga pembelajaran yang dipimpinnya tampak lebih baik dibanding pertemuan dan siklus sebelumnya. Akibatnya kreativitas dan hasil belaar mahasiswa pun lebih meningkat.

Meskipun masih tampak beberapa kelemahan, namun kelemahan tersebut dianggap tidak terlalu bermasalah sehingga tim peneliti sepakat mengakhiri kegiatan penelitian pada siklus kedua ini dengan memberikan rekomendasi agar dosen selalu mempertahankan dan meningkatkan kualitas pembelajarannya dengan menggunakan model-model pembelajaran yang inovatif.

\section{Hasil penelitian dan pembahasan Kemampuan Menyusun Rencana Pelaksanaan Pembelajaran}

Selama ini dosen mengaku tidak pernah menyusun rencana pelaksanaan pembelajaran (RPP) sebelum perkuliahan. Setelah diadakan diskusi tentang pembelajaran sejarah Indonesia kuno, secara bertahap terjadi perubahan. Diskusi yang diantaranya mencakup tentang pentingnya RPP tersebut mampu menanamkan kesadaran doseni. Ia sadar atas anggapan yang keliru selama ini, dan berjanji akan menyusun RPP setiap kali akan mengimplementasikannya dalam PBM. Setelah diadakan latihan penyusunan RPP, yaitu pada hari Rabu tanggal 12 Mei 2010, ternyata

Tabel 1. Kemajuan Dosen dalam Penyusunan RPP

\begin{tabular}{|l|l|l|l|}
\hline $\mathrm{N}$ & Indikator & Siklus I & Siklius II \\
\hline 1 & Perumusan kompetensi dasar & & \\
\hline 2 & Perumusan tujuan pembelajaran & Kurang & Baik \\
\hline 3 & Pengembangan materi pembelajaran & Baik \\
\hline 4 & Penetapan model/metode pembelajaran & Baik & Baik \\
\hline 5 & Penyusunan langkah-langkah pembelajaran & Cukup & Baik \\
\hline 6 & Penetapan media dan sumber belajar & Cukup & Cukup \\
\hline 7 & Penyusunan alat dan prosedur penilaian & Cukup & Baik \\
\hline
\end{tabular}


pada siklus pertama dosen mampu menyusun RPP. Setelah mendapat berbagai masukan akhirnya pada siklus kedua secara mandiri, dosen mampu menyusun RPP dengan lebih baik. Artinya beberapa kelemahan yang masih tampak pada siklus pertama, dapat diperbaiki pada siklus kedua.

\section{Kemampuan Melaksanakan Pembelajaran dengan Model Pemecahan Masalah Kreatif}

Menurut data yang diperoleh dari hasil observasi terhadap PBM yang dilaksanakan sebelum diadakan tindakan, dosen terkesan mengajar hanya untuk menyampaikan pengetahuan kepada mahasiswa. Hal itu berarti dosen memposisikan diri sebagai sumber pengetahuan, sedangkan mahasiswa hanyalah pihak yang pasif, sekedar menerima pengetahuan dari dosennya. Dalam observasi awal juga terungkap bahwa dosen mengajar dengan prosedur yang kurang tepat.

Setelah diadakan tindakan berupa diskusi tentang hakikat pembelajaran sejarah dan diadakan les model pembelajaran dengan penerapan model pemecahan masalah kreatif, akhirnya dosen peneliti dapat memperbaiki kemampuannya dalam melaksanakan proses pembelajaran di kelas. Kemajuan tersebut misalnya ditunjukkan sebagai berikut. Pada siklus pertama dosen sudah mampu mengimplementasikan prosedur pembelajaran dengan model PMK. Meskipun dalam pelaksanaannya belum maksimal, tetapi sudah cukup baik. Beberapa kekurangan yang masih tampak pada siklus pertama, akhirnya dianalisis dan direfleksikan kembali sebagai dasar untuk perbaikan rencana dan tindakan berikutnya. Setelah diadakan perbaikan rencana dan beberapa persiapan seperti les model pembelajaran, maka pada siklus kedua pelaksanaannya lebih optimal. Artinya dosen benar-benar mampu menerapkan model pemecahan masalah kreatif dalam pembelajaran sejarah Indonesia kuno. Beberapa kekurangan yang masih terlihat pada siklus pertama juga sudah tidak terjadi dalam siklus kedua.

\section{Penerapan Model Pemecahan Masalah Kreatif Dapat Meningkatkan Kreativitas Belajar Mahasiswa}

Masalah yang diangkat dalam penelitian ini adalah rendahnya kreativitas belajar mahasiswa. Hal itu terungkap pada saat diadakan observasi awal, yang terrefleksikan dari: banyaknya mahasiswa yang terlambat masuk kelas, mahasiswa pasif dalam perkuliahan; tidak ada yang bertanya, bahkan kalau ditanya tidak banyak yang mau menjawab, dan kalau pun ada kualitas jawabannya rendah. Di samping itu mahasiswa kurang memperhatikan perkuliahan: ada yang ngantuk, ngobrol dengan temannya, ada yang mencoret-coret, dan ada yang menggambar sendiri, sehingga suasana gaduh.

Setelah masalah itu digali lebih dalam, dianalisis, dan diadakan diskusi, peneliti merasa perlu menerapkan model pembelajaran yang tepat, yang memungkinkan terbentuknya budaya berpikir kreatif yang mampu menghasilkan pola berpikir komprehensif. Salah satu model pembelajaran inovatif yang diketahui dan dapat menumbuhkan kreativitas belajar mahasiswa adalah model pemecahan masalah kreatif. Melalui model ini, mahasiswa didorong memiliki sikap mandiri melalui proses kemampuan bekerja sama, partisipasi aktif, kemampuan merencanakan kegiatan belajar dari tugas-tugas terstruktur dengan mencari dan menghimpun data, informasi, fakta, serta berlatih mengemukakan pendapat. Model ini lebih memposisikan mahasiswa sebagai subyek belajar yang perlu dilibatkan secara aktif dalam PBM. Sementara itu dosen lebih berperan sebagai fasilitator, pembimbing, pendamping, dan koordinator dalam pembelajaran.

Setelah diadakan beberapa persiapan, dan diadakan tindakan berupa optimalisasi model pemecahan masalah kreatif dalam KBM, ternyata dari satu siklus ke siklus berikutnya meningkat juga kreativitas belajar mahasiswa.. Hal ini bisa dijelaskan, karena model pemecahan masalah kreatif menuntut kreativitas mahasiswa dalam mengeluarkan ide, gagasan dan pendapat mulai dari: identifikasi masalah, peumusan masalah, mencari dan mengumpulkan sumber, menganalisis sumber, sampai pada pemecahan masalah. Bahkan model ini juga menuntut setiap mahasiswa untuk ikut aktif dan kreatif dalam setiap tingkat pengakijian dan diskusi, yaitu mulai dari tingkat sub kelompok, kelompok, sampai diskusi kelas. 


\section{Penerapan Model Pemecahan Masalah Kreatif Dapat Meningkatkan Hasil Belajar Mahasiswa} Optimalisasi penerapan model pemecahan masalah kreatif ternyata bukan sekedar meningkatkan kreativitas belajar mahasiswa, tetapi juga mampu meningkatkan hasil belajarnya. Hal ini dapat dilihat dari arsip nilai mahasiswa, yang ternyata secara umum terjadi peningkatan mulai dari nilai awal mahasiswa (sebelum diadakan tindakan), nilai setelah diadakan tindakan pada siklus petama, sampai pada siklus kedua. Untuk lebih jelasnya dapat dilihat pada tabel berikut.

Tabel 2. Peningkatan Nilai Mahasiswa

\begin{tabular}{|l|l|c|c|c|}
\hline No & Indikator & $\begin{array}{c}\text { Pra Tin } \\
\text { dakan }\end{array}$ & $\begin{array}{c}\text { Siklus } \\
\text { I }\end{array}$ & $\begin{array}{c}\text { Siklus } \\
\text { II }\end{array}$ \\
\hline 1 & Nilai Terendah & 60 & 64 & 65 \\
2 & Nilai Tertinggi & 78 & 87 & 92 \\
3 & Nilai Rata-rata & 68 & 74 & 77 \\
\hline
\end{tabular}

Selama ini pembelajaran yang berlangsung cenderung menunjukkan: 1) guru lebih banyak ceramah; 2) media belum dimanfaatkan; 3) pengelolaan belajar klasikal dan kegiatan belajar kurang bervariasi; 4) tuntutan guru terhadap hail belajar rendah; 5) tidak ada pajangan hasil karya peserta didik; 6) guru dan buku sebagai sumber belajar. 7) semua peserta didik dianggap sama. 8) penilaian hanya berupa test. 9) latihan dan tugas-tugas kurang dan tidak menantang; dan 10) interaksi pembelajaran searah (Syaiful Sagala, 2009). Pembelajaran yang demikian tidak menunjukkan usaha yang berarti dari pihak gurunya, sehingga tidak akan memberikan hasil belajar yang berarti pula.

Mengajar menurut $\mathrm{H}$. Burton adalah upaya memberikan stimulus, bimbingan pengarahan, dan dorongan kepada peserta didik agar terjadi proses belajar (Syaiful Sagala, 2007). Sedangkan Gagne dan Brig (1979) mengemukakan bahwa pengajaran bukanlah sesuatu yang terjadi secara kebetulan, melainkan adanya kemampuan guru yang dimiliki tentang dasar-dasar mengajar yang baik. Menurut James B. Brow seperti yang dikutip oleh Suryosubroto (2002), tugas dan peranan guru antara lain: menguasai dan mengembangkan materi pelajaran, merencanakan dan mempersiapkan pelajaran sehari-hari, mengontrol dan mengevaluasi kegiatan siswa. Senada dengan pendapat tersebut, Jarolimek dan Foster (1976) mengemukakan bahwa mengajar mengandung tiga peranan besar yaitu: merencanakan, melaksanakan, dan mengevaluasi pembelajaran. Jadi mengajar adalah kegiatan belajar, sehingga proses belajar mengajar dapat berlangsung secara efektif dan efisien. Oleh karena itu, disarankan agar pembelajaran yang bersifat menghafal, dan pembelajaran yang bersifat menerima sebaiknya ditinggalkan para guru (Sukmadinata, Jami'at, dan Ahman, 2006).

Terkait dengan pembelajaran sejarah, para ahli seperti (Bank, 1985), (Sylvester, 1973), dan (Mays, 1974) sangat mengharapkan digunakannya sumber-sumber sejarah. Siswa harus berusaha menemukan bukti-bukti dari peristiwa masa lampau (sumber sejarah), mengolah atau mengadakan kritik terhadap sumber tersebut, menafsirkan, dan kemudian menyusunnya menjadi ceritera sejarah. Guru tidak lagi menjadi satu-satunya sumber informasi di kelas, tetapi lebih berperan dalam banyak dimensi, sebagai seorang pembimbing aktivitas siswa. Tugas siswa seperti seorang sejarahwan professional, meskipun baru pada tingkat perkenalan. Mereka dapat mengumpulkan, mengolah, menafsirkan, dan menyimpulkan sumber-sumber dengan berbagai macam cara, bahkan terpaksanya buku pelajaran sejarah di sekolah pun dapat dipakai sebagai sumber, tergantung dari bagaimana kita memperlakukan sumber tersebut (Hamid Hasan, 1985).

Apa yang telah diuraikan di atas menjadi landasan dan sekaligus sebagai kerangka acuan bagi pelaksanaan penelitian ini. Sebagaimana yang telah dikemukakan sebelumnya, yang menjadi masalah dalam penelitian ini adalah rendahnya kreativitas dan hasil belajar sejarah Indonesia kuno. Setelah digali sumber permasalahannya melalui observasi dan wawancara, kemudian didiskusikan dan dianalisis tim peneliti berkeyakinan bahwa masalah tersebut dapat diperbaiki melalui optimalisasi penerapan model pemecahan masalah kreatif dalam pembelajaran sejarah Indonesia kuno. Ternyata tindakan yang telah dilakukan oleh tim peneliti menjadi kenyataan. Sebagaimana telah dikemukakan 
pada bagian sebelumnya, bahwa optimalisasi penerapan model pemecahan masalah kreatif berdampak positif terhadap kreativitas mahasiswa. Temuan ini selaras dengan teori-teori yang telah dikemukakan di atas, bahwa dalam kegiatan belajar mengajar, tugas guru/dosen adalah mengorganisasi atau mengatur lingkungan dan menghubungkannya dengan peserta didik, sehingga terjadi proses belajar. Penerapan model pemecahan masalah kreatif pada gilirannya juga mampu meningkatkan hasil belajar mahasiswa.

Berdasarkan uraian di atas, dapat dinyatakan bahwa tindakan-tindakan yang telah dilakukan dalam penelitian ini dapat dipertanggungjawabkan baik secara teoritis maupun empiris. Secara teoritis tindakan-tindakan yang telah dilakukan oleh tim peneliti didukung oleh teori-teori yang relevan dengan masalah yang dihadapi. Secara empiris telah terbukti bahwa apa yang telah dilakukan oleh peneliti dapat meningkatkan kreativitas dan hasil belajar sejarah Indonesia kuno.

\section{Simpulan dan Saran Simpulan}

Pertama, masalah dalam penelitian ini adalah rendahnya kreativitas dan hasil belajar mahasiswa dalam mata kuliah Sejarah Indonesia Kuno. Masalah tersebut dapat diperbaiki melalui optimalisasi penerapan model pemecahan masalah kreatif. Keduanya secara bertahap mengalami peningkatan setelah diadakan tindakan dalam penelitian ini. Tindakan-tindakan yang yang dimaksud adalah: 1) diskusi tentang pembelajaran sejarah; 2) diskusi tentang metode, strategi dan pendekatan dalam pembelajaran sejarah, dan khususnya difokuskan pada penanaman konsep tentang model pemecahan masalah kreatif; 3) pelatihan penyusunan RPP; dan 4) les model pembelajaran, yang juga ditekankan pada peningkatan keterampilan dosen dalam menerapkan model PMK, yang meliputi langkah-langkah: 1) pendahuluan/orientasi; 2) kegiatan inti yang mencakup: (a) identifikasi masalah, (b) perumusan masalah, (c) pembagian kelompok dan sub kelompok, (d) pembahasan di tingkat sub kelompok dan kelompok, dan (e) diskusi kelas; dan 3) penutup. Kedua, optimalisasi penerapan model pemecahan masalah kreatif terbukti mampu meningkatkan kreativitas belajar mahasiswa. Hal itu dapat dilihat dari beberapa indikator, yaitu: 1) Mahasiswa berusaha memanfaatkan waktu belajar dengan sebaikbaiknya: tidak ada lagi yang terlambat masuk kelas, di dalam kelas mahasiswa sangat memperhatikan perkuliahan; 2) Mahasiswa terlibat aktif dan banyak ide atau gagasan dalam setiap langkah kegiatan, misalnya dalam kegiatan: identifikasi masalah, perumusan masalah, dan saat mengkaji masalah baik di tingkat sub kelompok maupun kelompok; 3) Mahasiswa cukup kreatif dalam mencari, mengumpulkan, dan menganalisis sumber-sumber yang relevan, baik dari buku-buku maupun internet; 4) Selama diskusi berlangsung, mayoritas mahasiswa dapat berpartisipasi aktif, ada yang bertanya dan ada yang menjawab dengan pertanyaan dan jawaban yang relevan dengan pokok permasalahan; 5) Suasana kelas selama KBM berlangsung tampak kondusif.

Ketiga, penerapan model pemecahan masalah kreatif pada akhirnya juga mampu meningkatkan hasil belajar mahasiswa. Hal ini dapat dilihat dari nilai terrendah, nilai tertinggi, dan rata-rata nilai mahasiswa yang cenderung mengalami peningkatan mulai dari sebelum diadakan tindakan, setelah diadakan tindakan pada siklus pertama, dan setelah siklus kedua.

\section{Saran}

Dari simpulan di atas, selanjutnya dapat diajukan saran sebagai berikut, Pertama, para guru dan dosen, khususnya para pengajar sejarah disarankan untuk meminimalisir penggunaan metode ceramah. Sebab metode ceramah hanya memposisikan peserta didik sebagai pihak yang pasip, yang hanya bisa menerima apa yang disampaikan guru/dosennya. Metode itu perlu ditinggalkan karena cukup membosankan dan tidak memberi tantangan pada peserta didik. Dalam hal ini para guru dan dosen sejarah diharapkan mencoba berbagai model pembelajaran yang mampu meningkatkan aktivitas, dan kreativitas peserta didik, sebab pembelajaran sejarah akan lebih berarti jika dapat dilakukan oleh peserta didik sendiri. Kedua, program Studi Pendidikan Sejarah sebagai tempat di mana penelitian ini dilakukan, diharapkan mempunyai 
gambaran yang jelas mengenai kualitas pembelajaran, dan aktivitas belajar mahasiswanya. Gambaran tersebut dapat dijadikan sebagai bahan pertimbangan dalam upaya pembinaan di program studi nya. Model tindakan yang ditawarkan dalam penelitian ini juga dapat dijadikan sebagai salah satu bentuk tindakan perbaikan kualitas pembelajaran mata kuliah yang lain. Tentu saja dengan berbagai penyesuaian yang relevan dengan masing-masing dosen, mata kuliah, dan mahasiswanya.

\section{Pustaka Acuan}

Bank, James A., 1985. Teaching Strategies for the Social Studies, New York: Longman, Inc.

B. Suryosubroto. 2002. Proses Belajar Mengajar di Sekolah. Jakarta: P.T. Rineka Cipta.

Brown, George, (1975). Micro Teaching, a Program of Teaching Skills. New York: Mithuen and Co, Ltd. Gagne dan Brigg, L. J. 1979. Principles or Instruction Design. New York: Holt Rinehart and Winston. Gunning, Denning, 1978. The Teaching of History. London: Croom Helm.

Hamid Hasan. 1985. Pengajaran sejarah antara Harapan dan Kenyataan. Makalah. Seminar Sejarah Nasional di Yogyakarta.

Hopkins, David., 1993. A Teacher's Guide to Classroom Research. Bristol: Open University Press.

Jarolimek, John., dan Clifor, D. Foster. 1976. Model of Teaching. New Jersey: Englewood Cliff Prenticehall Inc.

Kasihani Kasbolah, 2001. Penelitian Tindakan Kelas, Malang: Universitas Negeri Malang.

Mays, P. 1974. Why Teach History?, London: University of London Press.

Nasution, S. 1995. Didaktik Asas-asas Mengajar. Jakarta: Bumi Aksara.

Nugroho Notosusanto. 1979. Sejarah Demi Masa Kini. Jakarta: UI press.

Parnes, Sidney J. 1981. CPSI: The General System. Dalam: The Faces and Forms of creativity.

California: Printcraft Inc.

Simanjuntak, B., dan Pasaribu, LL. 1986. Pengantar Didaktik Metodik Kurikulum Proses Belajar Mengajar. Bandung: Tarsito.

Sukmadinata, N.S., Jami'at, A.N., dan Ahman. 2006. Pengendalian Mutu Pendidikan Sekolah Menengah: Konsep, Prinsip, dan Instrumen. Bandung: Refika Aditama.

Syaiful Sagala. 2007. Konsep dan Makna Pembelajaran untuk Membantu Memecahkan Problematika Belajar dan Mengajar. Bandung: Alfabeta.

Syaiful Sagala. 2009. Kemampuan Profesional Guru dan Tenaga Kependidikan. Bandung: Alfabeta.

Sylvester, D. 1973. Teaching History, London: Grom Helm, Ltd.

Tim Pelatih Proyek PGSM, 1999. Penelitian Tindakan Kelas: Bahan Pelatihan Dosen LPTK dan Guru Sekolah Menengah. Jakarta: Ditjen Dikti, Depdikbud.

Treffinger, Donald J. 1980. Encouraging Creative Learning for The Gifted and Talented: California: Venture County Superintended of School Office.

Widja, I Gde.. 1988. Pengantar Ilmu Sejarah: Sejarah dalam Perspektif Pendidikan. Semarang: Satya Wacana.

Widya, I Gde, 1989. Dasar-dasar Pengembangan Strategi Metode Mengajar Sejarah, Jakarta: Ditjen Dikti, Depdikbud. 